\title{
The economic viability of remote employment and the demand for worker skills amid rapid digital integration
}

\author{
Elena Avdeeva ${ }^{1, *}$, Tatiana Davydova ${ }^{1}$, Oksana Belyantseva ${ }^{1}$, and Svetlana Belyaeva ${ }^{1}$ \\ ${ }^{1}$ Voronezh State Technical University, Moscow Avenue, 14, Voronezh, 394026, Russia
}

\begin{abstract}
The positive impact of the virtual labour market development is examined, its capabilities and capacity, as well as the annual effect of the introduction of flexible employment forms, are evaluated. In particular, the features of the Russian labour market, which is starting to use virtual forms, are analyzed: the structure of the areas of employment of remote workers is still narrow - IT, programming; sales finance, accounting; online employment; design; customer support services. This tendency was especially pronounced in the context of a pandemic that changed the attitude of people towards distance work. It is emphasized that in the near future, each employee will have to have digital skills for work and social integration. WEF identifies five separate groups of demanded skills: business, specialized industry, general and soft skills, technical basic skills, technical breakthrough skills. Despite the fact that communication and thinking skills are brought to the forefront, digital skills allow people to create and share digital content, communicate and solve problems, to learn, perform work and social activities in an effective and creative way as a whole. The high level of employees with digital competencies at different levels in the company will provide it with a number of competitive advantages. Neoclassical models that reflect the relationship between economic growth and the growth of human capital are considered. State support for investments in education, research and development, accumulating new knowledge can be considered as the most important endogenous growth factor.
\end{abstract}

\section{Introduction}

In the context of the rapid integration of digital technologies into all spheres of human life, the classical labor market is gradually supplemented and, in part, replaced by a virtual market. Electronic, digital, virtual labor market is characterized as a system of economic relations between geographically distributed economic entities regarding the sale and purchase of labor information services [1].

\footnotetext{
* Corresponding author: avdeeva_ea@mail.ru
} 
Labor in the digital economy becomes autonomous and mobile, and the performance of labor functions is associated with the acquisition of additional competencies. The human potential and capital of workers operating in the information space receives information content and acquires new properties [2-4].

In the scientific literature, various concepts are considered: informal employment [5], atypical employment [6], distance employment [7-8], virtual employment [9]. The aspectual application examines the reduction of traditional employment in the context of the coronavirus pandemic [10], the motives and factors of employment, taking into account the skills of employment [11-12]. Ultimately, every telecommuting company defines a term for itself because it can be done entirely remotely or only partially. And there are a variety of tools a team uses to communicate with a remote worker.

In general, in the studies we studied, we are talking about the transformation of traditional labor relations, implying clearly defined rights and obligations for both employers and employees [13]. These relationships are increasingly being replaced by new and fluid forms of employment that create a class of "digital workers" [9]. At the same time, digital employment is classified as distance, or remote, which, in turn, is a non-standard form of employment.

\section{Experimental}

In a study of remote employment in the Russian Federation, conducted by Bitrix 24 and J'son $\&$ Partners Consulting, it is noted that the annual effect due to the introduction of a flexible and efficient organization of working time is estimated at 27 billion rubles, savings on the maintenance of an office workplace - at 38 billion rubles, expanding the geography of recruitment and reducing labor costs - in the amount of 3 billion rubles. [7].

Analyzing the positive impact of the development of the virtual labor market, the researchers emphasize the possibility of solving a number of urgent problems. These include the adaptation of white collars released in the process of digitalization; prevention of stagnant unemployment; involvement of socially vulnerable strata of the population in the economically active population, solution of environmental problems [1, 14-17]. Taking into account the possibilities of the virtual labor market, it was concluded that it can help to find ways to adapt to such serious challenges from the external environment as changing the nature of many professions or their complete disappearance [18-20], shortening the life cycle of a profession and strengthening the role of competencies, the polarization of the employed and the gradual displacement of professions requiring an average level of qualifications [21], an increase in the period of retirement [22].

A significant number of employees with digital skills at different levels of the company will give you a competitive edge. In the corporate world, companies are characterized by digital champions, in which the ability of employees to acquire digital skills is well above the market average. This applies not only to specialized employees whose work is related to ICT, but also to all personnel of the company and its management, in the first place [23, 24]. Such companies are more efficient in their activities, especially due to the ability to:

- apply the best business models that adequately meet the needs of the digital world;

- reduce the time to market for goods and services, use digital marketing and revenues from startups;

- optimize the cost structure through the use of technology platforms;

- use high quality digital products to invest in digital talent;

- to ensure high customer satisfaction with product quality

- work with personalized offers and personalized digital experiences. 
Distance employment is relatively new for Russia (69\% of respondents have been involved in distance employment for 5 years or less). Most teleworkers are young people from generation $\mathrm{Z}$, or the digital generation, which is characterized by a new communicative culture.

According to the sociological survey of 2019, conducted by the "snowball" method with the participation of 196 respondents, the structure of employment spheres for remote workers was revealed: IT, programming (29\%); sales (20\%); finance, accounting (10\%); Internet employment (11\%); design (7\%); customer support services $(6 \%)$; insurance $(2 \%)$ [8]. In other professions, however, a presence is required: retailers, nurses, and artisans cannot work remotely.

The survey showed that more than half of the respondents did not formalize distance work with an employment contract. The main reasons for choosing this form of employment are flexible working hours and additional earnings [8].

If we evaluate its virtual form in the structure of remote employment, then it is remote virtual employment and freelancing. According to published data, today in the virtual market $51 \%$ are programmers, $27 \%$ are designers, $15 \%$ are analysts, $15 \%$ are financial support employees. Popular professions include webmasters, translators, advertisers, etc. [7].

\section{Evaluation}

Great importance is attached to the skills of employment that are in demand by employers in the new conditions [25]. Accordingly, the importance of digital skills in employment is emphasized, including in connection with the need to reduce the digital inequality in countries of the world, the level of welfare of citizens, in the gender aspect [26; 27].

The European Commission argues that digital literacy should include digital collaboration, security and problem solving skills. Digital literacy includes the personal, technical, and intellectual (digital) skills needed to live in a digital world. Basic digital skills - working with various technical devices, files, the Internet, online services, applications. It also includes psychomotor skills such as typing (fine motor skills) or touchscreen (gesture development) [28].

The digital revolution will change the future of work and jobs. With rapid change, businesses will increasingly interact with complex digital ecosystems that span a range of enterprises and technologies, artificial intelligence, the Internet of Things, or automated devices. By 2025 , industrial automation is projected to grow from $29 \%$ in 2108 to $52 \%$ (Fig. 1). 


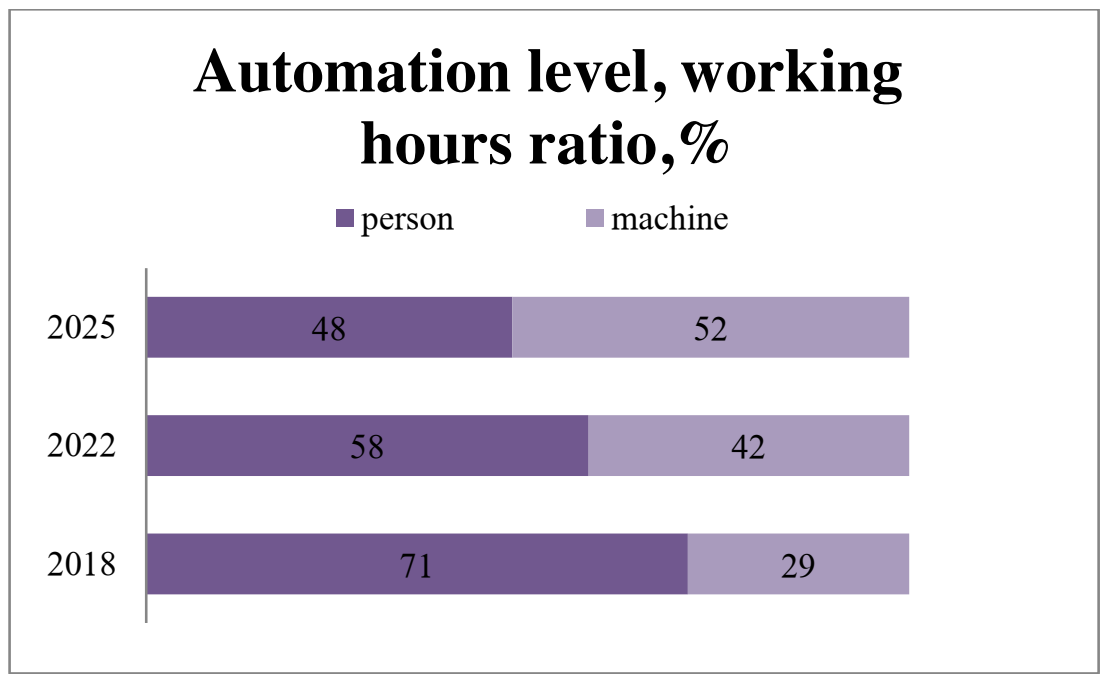

Source: Future of Jobs Survey 2018, World Economic Forum.

Fig. 1. Forecast of the level of automation by 2025.

According to the World Economic Forum, if current growth trends continue, these new professions will provide 1.7 million new jobs in 2020 and 2.4 million jobs by 2022 . Over the next three years will appear:

- $37 \%$ of opportunities in a care economy

- $17 \%$ in sales, marketing and content

- $16 \%$ in data and AI

- $12 \%$ in engineering and cloud computing

- $10 \%$ in product development

- $8 \%$ in people and culture

- green professions are still in low demand [28].

The jobs with the highest growth rates in large volumes of work include artificial intelligence specialists, transcription specialists, data processing specialists, customer success specialists, and full-stack engineers. Among jobs with smaller volumes, the greatest growth is observed among landfill biogas technicians, social media assistants, wind turbine service technicians, environmentalists and marketers.

The growing demand for fast-growing professions has further impacted the value of the whole range of distinctive skills that underlie these seven professional clusters and their promise of growth and prosperity in the new economy. These required skills can be divided into five separate skill groups:

- business skills;

- specialized industry skills;

- general and soft skills;

- technical basic skills;

- technical breakthrough skills.

Skills are understood as an automatism-developed skill that is based on knowledge. To form it, you need to learn and practice. Skills related to each distinctive group (see table 1).

Table 1. Classification of skills 


\begin{tabular}{|l|l|}
\hline $\begin{array}{l}\text { 1. Business skills - the ability to } \\
\text { perform certain labor duties. }\end{array}$ & $\begin{array}{l}\text { Delegation, communication, negotiation, } \\
\text { analytical, strategic planning, teamwork, general } \\
\text { management skills, leadership skills, stress } \\
\text { resistance, etc. }\end{array}$ \\
\hline $\begin{array}{l}\text { 2. Specialized industry skills - } \\
\text { knowledge of the specifics of the } \\
\text { functioning and development of the } \\
\text { industry }\end{array}$ & $\begin{array}{l}\text { Commercial awareness, communicative, } \\
\text { attention to detail, creativity, adaptability, } \\
\text { analytical thinking, perseverance, motivation, } \\
\text { sustainability, etc. }\end{array}$ \\
\hline $\begin{array}{l}\text { 3. Solid (general) skills - learning } \\
\text { abilities or skill sets that are easy to } \\
\text { quantify. They are acquired as a } \\
\text { result of studying at school or } \\
\text { courses, as a result of reading books. }\end{array}$ & $\begin{array}{l}\text { Foreign language proficiency, degree or } \\
\text { certificate, printing speed, machine operation, } \\
\text { computer programming, etc. }\end{array}$ \\
\hline $\begin{array}{l}\text { 4. Soft skills are non-technical skills } \\
\text { related to your work. }\end{array}$ & $\begin{array}{l}\text { They include how you interact with colleagues, } \\
\text { how you solve problems and how you manage } \\
\text { your work, "interpersonal communication } \\
\text { skills": communication, flexibility, leadership, } \\
\text { motivation, patience, persuasiveness, problem } \\
\text { solving ability, teamwork, time- management, } \\
\text { work ethics, etc. }\end{array}$ \\
$\begin{array}{l}\text { programming languages, common operating } \\
\text { systems, software knowledge, technical writing, } \\
\text { project management, data analysis, etc. These } \\
\text { skills vary greatly depending on the industry and } \\
\text { type of work. }\end{array}$ \\
\hline $\begin{array}{l}\text { 5. Technical basic skills are qualities } \\
\text { acquired in the field of mathematics, intuition skills, programming tools and } \\
\text { computer science, mechanics, } \\
\text { information technology. } \\
\text { easy adaptation to technological } \\
\text { innovations }\end{array}$ & $\begin{array}{l}\text { languages, data transfer and visualization, basic } \\
\text { understanding of statistical methods and tests, } \\
\text { data mixing and transformation, knowledge and } \\
\text { application of machine learning algorithms. }\end{array}$ \\
\hline
\end{tabular}

Employers are increasingly looking for candidates with hybrid skills, which are a combination of soft and technical skills. Candidates with this skill set are very competitive in an ever-evolving, technology-oriented economy. There are currently very few highly qualified specialists with the entire set of required skills. Naturally, they are in demand by large corporations. Mass mastery of the necessary skills requires a review of the current education system, the adjustment of curricula and advanced training of teachers, the organization of advanced training in the workplace. Costs in this direction are justified and can be considered as investments in human capital.

At the end of XX century qualitatively new theoretical models appeared, the authors of which tried to justify the endogenous nature of technological changes that give rise to economic growth. The production function of these models contains a new variable - human capital - characterizing the volume of scientific knowledge and practical experience accumulated in the learning process. Various approaches have been developed to model the relationship between human capital and economic growth. Researchers focus on the consequences of the human capital accumulation (Lucas - Uzawa model), on the relationship between economic growth and financing of education (Glomme - Ravikumar model), on the role of human capital in technology adaptation, if knowledge is considered as an innovative factor (Nelson - Phelps model) [29]. Models of economic growth that take into account human capital are becoming increasingly complex in structure. Thus, in accordance with growth models in one sector, in which total costs are described by a function, determined by 
physical and human capital, models of two sectors are created. In addition to the output function, two-sector models separately describe the process of human capital "production" and explain the effects of human and physical capital on the economic growth of countries.

Let's look at the main elements of the approach of G. Mankyu, D. Romer and D. Whale (1992) to determine the contribution of human capital to the country's economic growth - the MRW model [30]. This approach is one of the most famous and was tested in the study of growth dynamics for a large number of countries with positive and negative dynamics of production. Authors included human capital in the production function as an independent factor of economic growth, and the production function acquired the following form:

$$
Y=K^{\alpha} \cdot H^{\beta} \cdot(A \cdot L)^{1-\alpha-\beta}
$$

where $\alpha$ - is the coefficient of elasticity of output Y by the factor of physical capital, $\beta$ - is the coefficient of elasticity of output by the factor of human capital,

$1-\alpha-\beta$ - is the coefficient of elasticity of output by the factor of labour, AL is the number of effective labour units. Then the production function, calculated per employee, taking into account human capital, is converted into the expression:

$$
y=\mathrm{k}^{\alpha} \cdot \mathrm{h}^{\beta}
$$

where $\mathrm{k}$ - is the growth rate of the stock of physical capital per employee, $\mathrm{h}$ - is the growth rate of the stock of human capital per employee.

Testing the model on empirical data showed that the further the country goes in its economic development, the greater the role for the growth of the economy is played by the quality or level of human capital development. Factors such as unskilled labour and physical capital become relatively more passive, neutral and do not cause noticeable shifts in the volume of production.

When researching economic growth, it is necessary to take into account that investments, including in human capital, and innovative activity have a significant external effect, since the whole society can use their results in the form of an increase in accumulated knowledge. K. Arrow's growth model has the form:

$$
Y=\mathrm{K}^{\mathrm{a}+z} \cdot L^{1-a}
$$

where $\mathrm{z}$ - is the coefficient of elasticity of total output (Y) in relation to the public stock of production and managerial knowledge. An important role in the use of such knowledge is played by experiential learning. The model shows that the more products are produced, the more discoveries of inventions occur and, therefore, it becomes possible to produce even more. P. Romer, who continued the development of this model, argued that accumulated capital, as well as knowledge accumulated in society, automatically lead to the effect of increasing returns to scale, respectively, in formula (3) the condition should be fulfilled:

$$
(a+z)>1
$$

Slowly developing production makes it impossible to develop technology and improve the skills of workers. Thus, government support for investment in education, research and development, accumulating new knowledge can be considered as the most important endogenous growth factor. 
Slowly developing production makes it impossible to develop technology and raise the qualifications of workers. Thus, government support for investment in education, research and development, accumulating new knowledge can be considered as the most important endogenous growth factor. Performance assessment often includes both core competencies required by the organization and competencies specific to the employee's job. The evaluator, often a supervisor or manager, will provide the employee with constructive, actionable feedback based on the evaluation. This, in turn, gives the employee the direction they need to improve and develop their work. Employers began to include questions in their hiring questionnaires that identify professionalism and time management skills, technical skills and virtual communication skills in a team, discipline, and the ability to work in isolation. Professions in which you mainly write, design, program or make phone calls are ideal for remote work, for example: accountant, software developer, graphic designer, internet marketer, project manager, copywriter - blogger, translator, virtual assistant, web -designer or homepage designer.

Factors influencing labor productivity include the following: skills and qualifications of workers, nature of employment, employee morale, technological progress, replacement of capital for labor, capacity utilization, investment levels. In the long term, the level of investment in $\mathrm{R} \& \mathrm{D}$, new technologies and best practices are very important in determining productivity growth.

\section{Conclusions}

Remote workers are part of the future of all industries. Any type of organization can reap tremendous benefits by relying on freelance strength. A good strategy is needed to help you find and hire the right people for your team.

In connection with the urgent need for new digital soft competencies, both for the Russian and for the labor markets of other countries, we believe it is advisable:

- to formulate basic requirements for the basic competencies of the digital economy for each level of education;

- develop a regulatory framework for educational programs that are essential for the digital economy;

- to create comfortable conditions for attracting qualified employees of the IT industry for teaching in the system of vocational education in information technology.

Given that the skill requirements for new professions are very different from today's requirements for surplus professions, active, strategic and focused efforts from all stakeholders will be required to develop new profession maps and stimulate labor redistribution.

Digital technologies are key to ensuring that economies and government agencies such as offices and schools can operate even in emergency crises such as a pandemic. Earlier it seemed incredible that mobile work and mobile learning could become the standard, but now the world community has recognized the huge potential of digital technologies not only in the fight against the virus, but also in a number of other positive aspects: as well as in reducing carbon dioxide emissions from for the fact that most of the workers stayed at home. Many companies have appreciated the efficiency and potential of home offices. Policymakers must modernize labor laws, such as replacing the rigid eight-hour day with a maximum weekly working time, adopting hourly wages. 


\section{References}

1. T. B. Rusakova, The essence and directions of development of the virtual labor market in the Russian Federation, SPbSPU Scientific and Technical Bulletin. Economic Sciences, 5(12), 44-57 (2019) DOI: 10.18721 / JE.12504

2. S. A. Dyatlov, M. A. Dobrokhotov, Forms of implementation of human capital in the digital economy, Bulletin of the St. Petersburg State University of Economics, 4(112), 25-28 (2018)

3. E. Avdeeva, T. Davydova, O. Belyantseva, T. Makeeva, Factors of Sustainable Development of Energy Technologies in the Formation of Digital Economy, E3S Web of Conferences, 164, 09045 (2020) DOI: 10.1051 / e3sconf / 202016409045

4. T. Davydova, E. Avdeeva, L. Kochetova, T. Makeeva, Methodological approach to the formation and implementation of the human potential of the region, Proceedings of the Volgograd State University International Scientific Conference "Competitive, Sustainable and Safe Development of the Regional Economy "(CSSDRE 2019), Advances in Economics, Business and Management Research, 83, 204-207 (2019) Doi: 10.2991 / cssdre-19.2019.41

5. E. A. Jackson, Informal Employment. In: Leal W. Filho, A. Azul, L. Brandli, P. Özuyar, T. Wall (eds) Decent Work and Economic Growth. Encyclopedia of the UN Sustainable Development Goals. Springer, Cham (2020)

6. N. V. Chernykh, The influence of atypical forms of employment on theoretical ideas about labor relations, Actual problems of Russian law, 8(105), 108-117 (2019) DOI: 10.17803 / 1994-1471.2019.105.8.108-117

7. Bitrix24, J'son \& Partners Consulting: Distance employment as a way to improve business efficiency and a new trend in the labor market. Prospects for distribution in Russia, 2014-2020 (2015) http://json.tv/ict_telecom_analytics_view/polnaya-versiyaprezentatsii-generalnogo-direktora-svetlany-vodyanovoy-s-presskonferentsii-bitriks24i-json-partners-consulting-20150617030352, (last accessed 21.01.2021)

8. E. S. Dashkova, V. E. Zvyagintseva, Distance employment: assessment and directions of regulation, Bulletin of Voronezh State University. Series: Economics and Management, 1, 83-88 (2020) DOI 10.17308 / econ.2020.1 / 2758

9. C. Bin, L. Tao, W. Yingqi, Volatile Fragility: New Employment Forms and Disrupted Employment Protection in The New Economy, International Journal of Environmental Research and Public Health, 17(5), 1531 (2020) Doi: 10.3390 / ijerph17051531

10. D. Joystu, M. Ankita, Z. Sufia, M. Abhijit, Lockdown and Beyond: Impact of COVID19 pandemic on global employment sector with special reference to India, NUJS Journal of Regulatory Studies, Special Edition April, 1-4 (2020)

11. J. C. A. Calvo, G. M. García, The influence of psychological capital on graduates' perception of employability: the mediating role of employability skills, Higher Education Research \& Development (2020). DOI: 10.1080/07294360.2020.1738350

12. P. A. M. Bremner, The gap between degree outcomes and employability skills. 15th Enhancement Conference, Evaluation, Evidence and Enhancement: Inspiring Staff and Students, Jun. 2018. Glaswow (2018)

13. T. Averina, E. Avdeeva, O. Perevalova, Introduction of management innovations in the work of municipal organizations, E3S Web of Conferences, 01121 (2018).

14. K. Kulakov, S. Belyaeva, O. Belyantseva, A. Gamisoniya, Sustainable economic development at the mesoscale: factors and ratings, MATEC Web of Confe-rences, 170, 01118 (2018) 
15. Yu. V. Bondarenko, T. A. Sviridova, T. A. Averina, Aggregated multi-criteria model of enterprise management, taking into account the social priorities of the region. IOP Conference Series: Materials Science and Engineering The international seminar "Advanced Technologies in Materials Science, Engineering and Automation - MIP: Engineering - 2019". Krasnoyarsk Scientific and Technical Mayor's Office of the Russian Union of Scientific and Technical Associations (2019).

16. E. Serebryakova, E. Smorodi-na, O. Belyantseva, I. Kryuchkova, Formation of the infrastructure of the waste processing cluster, In the collection: E3S Web of Conferences, 01035 (2020)

17. V. V. Gasilov, I. V. Kryuchkova, Evaluation of the economic efficiency of the use of secondary resources in construction, FES: Finance. Economy, 11, 5-8 (2012)

18. A. Sorgner, Automation of jobs: a threat to employment or a source of entrepreneurial opportunity? Foresight and STI Governance, 11(3), 37-48 (2017)

19. Atlas of new professions: the second edition of the Agency for Strategic Initiatives and Skolkovo LNA, Moscow. (2015) https://skolkovo.ru /public/media/documents/research/sedec/SKOLKOVO_SEDeC_Atlas.pdf (last accessed 22.05.2020)

20. Yu. Bondarenko, T. Azarnova, I. Kashirina, T. A. Averina, Aggregation models and an algorithm for reconciling the interests of the region and enterprises of the energy sector, Advances in the field of intelligent systems and computing, 983, 69-78 (2019)

21. D. H. Autor, D. Dorn, The Growth of Low-Skill Service Jobs and the Polarization of the US Labour Market, American Economic Review, 103(5), 1553-1597 (2013)

22. M. B. Denisenko, E. Ya. Varshavskaya, Duration of working life in Russia, HSE Journal of Economics, 21(4), 592-622 (2017)

23. S. A. Barkalov, O. S. Perevalova, T. A. Averina, Development of an algorithm for maximizing the financial results of an investment program. Proceedings of 2018. 11th International Conference "Management of the Development of Large-Scale Systems", MLSD, 8551863 (2018)

24. E. N. Zhutaeva, E. A. Serebryakova, I. V. Kryuchkova, Formation of a new waste management system based on the cluster approach in the Voronezh region, Economics and Entrepreneurship, 9-4(86), 979-982 (2017)

25. E. Smith, Employability Skills, International Encyclopedia of Education (Third Edition) 368-375 (2010)

26. C. Krish, A. Urvashi, M. Vidisha, G. Nozibele, J. Jaya, Bridging the digital divide in the G20: skills for the new age, Economics: The Open-Access, Open-Assessment E-Journal, 12(2018-24), 1-20 (2018) http://dx.doi.org/10.5018/economics-ejournal.ja.2018-24 (last accessed 28.05.2020)

27. A. R. Safiullin, O. A. Moiseeva, Digital Inequality: Russia and other countries in the Fourth industrial revolution, St. Petersburg State Polytechnical University Journal Economics, 12(6), 26-37 (2019) DOI: 10.18721 / JE.12602

28. http://www3.weforum.org/docs/WEF Future of Jobs 2018.pdf (last accessed 28.05.2020)

29. R. E. Lucas, Lectures on economic growth, trans. from English, 288 (Gaidar Institute Publishing House, Moscow 2013)

30. G. Mankiw, Contribution to the Empirics of Economic Growth, December, 3541, NBER Working Paper (1990) 